\title{
Reaction behavior of lignin in supercritical methanol as studied with lignin model compounds
}

$\operatorname{AUTHOR}(S)$ :

Minami, Eiji; Kawamoto, Haruo; Saka, Shiro

\section{CITATION:}

Minami, Eiji ...[et al]. Reaction behavior of lignin in supercritical methanol as studied with lignin model compounds. Journal of Wood Science 2003, 49: 158-165

\section{ISSUE DATE:}

2003-04

URL:

http://hdl.handle.net/2433/250168

\section{RIGHT:}

This is a post-peer-review, pre-copyedit version of an article published in Journal of Wood Science. The final authenticated version is available online at: http://dx.doi.org/10.1007/s100860300025.; この論文は出版社版でありませ ん。引用の際には出版社版をご確認じ利用ください。; This is not the published version. Please cite only the published version. 


\section{Title page}

Original article

Title

Reaction behavior of lignin in supercritical methanol as studied with lignin model compounds

Authors

Eiji Minami • Haruo Kawamoto • Shiro Saka

Eiji Minami • Haruo Kawamoto • Shiro Saka( $\bowtie)$

Department of Socio-Environmental Energy Science, Graduate School of Energy Science, Kyoto University, Yoshida-honmachi Sakyo-ku, Kyoto, 606-8501, Japan

Tel/Fax: +81-(0) 75-753-4738

E-mail: saka@energy.kyoto-u.ac.jp

*This study was presented in part at the 45th Lignin Symposium in Ehime, Japan, Oct. 26-27, 2000 and the 52nd Annual Meeting of the Japan Wood Research Society in Gifu, Japan, April 2-4, 2002.

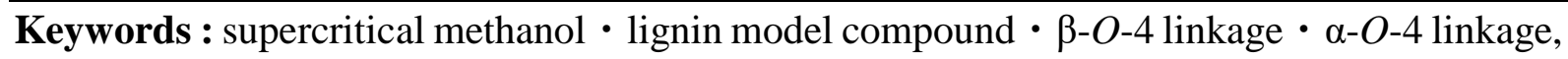
$\beta-1$ linkage $\cdot 5-5$ linkage 
Abstract: Some lignin model compounds were studied on the reaction behaviors of lignin and its kinetics in supercritical methanol with a batch-type supercritical biomass conversion system. Guaiacol, veratrole, 2,6-dimethoxyphenol and 1,2,3-trimethoxybenzene were used as model compounds for aromatic rings in lignin. Besides, $5-5, \beta-1, \beta-O-4$ and $\alpha-O-4$ types of dimmeric lignin model compounds were used as representatives of linkages in lignin. As a result, aromatic rings and 5-5 (biphenyl) type structures were stable in supercritical methanol. Furthermore, $\beta-1$ linkage was not cleaved in the $\beta-1$ type structure but converted rapidly into stilbene. On the other hand, $\beta$-ether and $\alpha$-ether linkages of $\beta-O-4$ and $\alpha-O-4$ lignin model compounds were cleaved rapidly and these compounds decomposed to some monomeric compounds. However, phenolic compounds were found to be more reactive than non-phenolic compounds. These results indicate that cleavages of ether linkages mainly contribute to the depolymerization of lignin, whereas condensed linkages like 5-5 and $\beta-1$ types are not cleaved in supercritical methanol. Therefore, it is suggested that the supercritical methanol treatment is effective to depolymerize lignin into the lower molecular products as methanol-soluble portion mainly by the cleavage of $\beta$-ether structure which is the dominant linkage in lignin. 


\section{Introduction}

In our laboratory, the supercritical fluid biomass conversion system with a batch-type reaction vessel ${ }^{1-5}$ has been applied to study the chemical conversion of woody biomass to obtain useful chemicals and liquid fuels. For example, the supercritical water $\left(>374^{\circ} \mathrm{C}\right.$, $>22.1 \mathrm{MPa}$ ) treatment of cellulosic biomass has been studied by Saka and his coworkers. ${ }^{2-4}$ However, hydrolysis products such as glucose were further decomposed rapidly in supercritical water due to its high critical temperature. Therefore, they also have studied the chemical conversion of biomass resources in supercritical methanol $\left(>239^{\circ} \mathrm{C},>8.09 \mathrm{MPa}\right),{ }^{1,6}$ which could offer the milder conditions of the reaction than supercritical water due to its lower critical temperature.

Woody biomass is a complex of natural polymer substances: cellulose, hemicelluloses and lignin. These polymer substances constitute the cell walls of wood and form their fine structures. Especially, lignin is a complex material with dehydrogenatively polymerized structure of phenylpropane $\left(\mathrm{C}_{6}-\mathrm{C}_{3}\right)$ units, which have guaiacyl and syringyl nuclei with various ether and condensed linkages, and behaviors of natural lignin in supercritical fluid remained unclear.

Yokoyama et al. ${ }^{7}$ have, thus, studied the degradation of organosolv lignin in supercritical water and supercritical methanol, and reported the oil and char yields related to the reaction conditions. They also have studied the mechanisms of lignin degradation in supercritical methanol using model compounds including dibenzyl ether, benzaldehyde, benzyl methyl ether ${ }^{8}$ and benzyl phenyl ether. ${ }^{9}$ However, aromatic rings of these model compounds do not have any substitutional groups such as hydroxyl and methoxyl groups, which are expected to play important roles in the reaction of lignin. In this paper, therefore, a series of simple aromatic model compounds and dimeric 5-5 (biphenyl), $\beta-1, \beta-O-4$ and $\alpha-O-4$ lignin model 
compounds were studied on the reaction behaviors of lignin in woody biomass in supercritical methanol.

\section{Materials and methods}

Lignin model compounds

Figure 1 shows the lignin model compounds used in this study for supercritical methanol treatment. Guaiacol (1) and veratrole (2) were used as model compounds for guaiacyl nuclei, while 2,6-dimethoxyphenol (3) and 1,2,3-trimethoxybenzene (4) were for syringyl nuclei, all purchased from Nakalai Tesque, Inc. as guaranteed grade agents. 2,2'-dihydroxy-3,3'-dimethoxy -5,5'-dimethylbiphenyl (5) and 2,2',3,3'-tetramethoxy-5,5'-dimethylbiphenyl (6) were selected for 5-5 linkages and prepared according to the method described by Kratzl and Vierhapper, ${ }^{10}$ whereas 1,2-(3,4-dimethoxybenzyl)-1,3-propanediol (7) (erythro form) was for $\beta$-1 linkage, prepared by the method of Kristersson and Lundquist. ${ }^{11}$ For $\beta-O-4$ linkages, guaiacylglycerol- $\beta$-guaiacyl ether (8) (erythro form) and veratrylglycerol- $\beta$-guaiacyl ether (9) (erythro form) were prepared according to the method of Nakatsubo et al. ${ }^{12}$ For phenolic and non-phenolic $\alpha-O-4$ linkages, 4-O-(4-hydroxy-3-methoxybenzyl)guaiacol (10) and 4-O-(3,4-dimethoxybenzyl)guaiacol (11) were prepared, respectively. The former was prepared from 4-benzyloxy-3-methoxybenzyl bromide obtained by brominating 4-O-benzyl vanillyl alcohol with an excessive amount of guaiacol and potassium carbonate in N,N-dimethylformamide. The latter was prepared by similar condensation of 3,4-dimethoxybenzyl bromide with guaiacol. 
Supercritical methanol treatment

A batch-type supercritical biomass conversion system ${ }^{1-5}$ was applied for supercritical methanol treatment. In case of methanol, this system can cover a range in pressure and temperature up to about $100 \mathrm{MPa}$ and $500^{\circ} \mathrm{C}$ with a constant density of $0.79 \mathrm{~g} / \mathrm{ml}$. To start a treatment of lignin model compounds in supercritical methanol, the reaction vessel with 10.0mg lignin model compound dissolved in $5.0 \mathrm{ml}$ of methanol was quickly heated by immersing it into the tin bath preheated at an adequate temperature, and maintained under supercritical conditions for 1 to 30min. The obtained supercritical conditions of methanol were in a range between 255 and $350^{\circ} \mathrm{C}$ in temperature and 24 and $43 \mathrm{MPa}$ in pressure, mainly in $270^{\circ} \mathrm{C}-27 \mathrm{MPa}$ and $350^{\circ} \mathrm{C}-43 \mathrm{MPa}$. After an adequate reaction time, the reaction vessel was moved into the water bath to quench the reaction. The detailed profiles of the temperature and pressure in the reaction vessel are described in previous works. ${ }^{1,5}$

Analysis of the reaction mixture

The obtained reaction mixture was, then, directly analyzed by high performance liquid chromatography (HPLC) carried out with Shimadzu LC-10A under the following conditions: column; STR ODS-II, flow rate; $0.8 \mathrm{ml} / \mathrm{min}$, eluent; 1$) \mathrm{CH}_{3} \mathrm{OH} / \mathrm{H}_{2} \mathrm{O}=20 / 80 \rightarrow 100 / 0(0 \rightarrow$ 35min), 2) $\mathrm{CH}_{3} \mathrm{OH} / \mathrm{H}_{2} \mathrm{O}=20 / 80 \rightarrow 60 / 40 \rightarrow 100 / 0(0 \rightarrow 40 \rightarrow 50 \mathrm{~min})$, detector; $\mathrm{UV}_{280 \mathrm{~nm}}$, temperature; $40^{\circ} \mathrm{C}$. Gel permeation chromatography (GPC) was also carried out for the reaction mixture with Shimadzu LC-10A under the following conditions: column; Shodex KF-801 (exclusion limit: MW 1,500 in polystyrene), flow rate; $1.0 \mathrm{ml} / \mathrm{min}$, eluent; tetrahydrofuran (THF), detector; $\mathrm{UV}_{280 \mathrm{~nm}}$, temperature; $40^{\circ} \mathrm{C}$. Gas chromatography-mass spectrometry (GC-MS) was performed on HITACHI G-7000M and M-9000. Most products in the reaction 
mixtures were identified by comparison with the authentic samples on GC-MS analysis. Besides, some reaction products were separated by preparative thin layer chromatography (TLC) on silica gel plate (Kieselgel $60 \mathrm{~F}_{254}$, Merk) with ethyl acetate and $n$-hexane (1:1). The isolated compounds were then analyzed by proton nuclear magnetic resonance ( $\left.{ }^{1} \mathrm{H}-\mathrm{NMR}\right)$ spectroscopy, in which its spectra were recorded in $\mathrm{CDCl}_{3}$ with Varian AC-300 (300MHz) spectrometer with tetramethylsilane (TMS) as an internal standard. 3,3',4,4'-tetramethoxystilbene (trans form) and 1-guaiacyl-1-veratrylmethane (o- and $p$ isomers) were identified by ${ }^{1} \mathrm{H}-\mathrm{NMR}$ analysis. 3,3',4,4'-tetramethoxystilbene (trans):

${ }^{1} \mathrm{H}-\mathrm{NMR}\left(\mathrm{CDCl}_{3}, 300 \mathrm{MHz}\right) \delta: 3.88\left(6 \mathrm{H}, \mathrm{s},-\mathrm{OCH}_{3}\right), 3.93\left(6 \mathrm{H}, \mathrm{s},-\mathrm{OCH}_{3}\right), 6.90(2 \mathrm{H}, \mathrm{s},=\mathrm{C}-\mathrm{H})$, 6.83-7.04(6H, m, aromatic H). 1-guaiacyl-1-veratrylmethane (o- and $p$ - isomers): ${ }^{1} \mathrm{H}-\mathrm{NMR}$ $\left.\left(\mathrm{CDCl}_{3}, 300 \mathrm{MHz}\right) 1\right) \delta: 3.80\left(3 \mathrm{H}, \mathrm{s},-\mathrm{OCH}_{3}\right), 3.81\left(3 \mathrm{H}, \mathrm{s},-\mathrm{OCH}_{3}\right), 3.83\left(3 \mathrm{H}, \mathrm{s},-\mathrm{OCH}_{3}\right)$, 3.84(2H, s, C-H), 5.46(1H, s, -OH), 6.63-6.83(6H, m, aromatic H); 2) $\delta: 3.81\left(3 \mathrm{H}, \mathrm{s},-\mathrm{OCH}_{3}\right)$, 3.82(3H, s, $\left.-\mathrm{OCH}_{3}\right), 3.86\left(3 \mathrm{H}, \mathrm{s},-\mathrm{OCH}_{3}\right), 3.92(2 \mathrm{H}, \mathrm{s}, \mathrm{C}-\mathrm{H}), 5.71(1 \mathrm{H}, \mathrm{s},-\mathrm{OH}), 6.72-6.80(6 \mathrm{H}, \mathrm{m}$, aromatic $\mathrm{H})$.

\section{Results and discussion}

Table 1 shows the number of different types of linkages upon 100 phenylpropane $\left(\mathrm{C}_{6}-\mathrm{C}_{3}\right)$ units involved in softwood and hardwood lignins. ${ }^{13,14}$ It is apparent that hardwood lignin has more ether linkages than softwood lignin. In this study, therefore, reactivity of lignin was investigated focusing on the $5-5, \beta-1, \beta-O-4$ and $\alpha-O-4$ linkages, because these are dominant in the lignin structure. 
Reactivity of aromatic rings in lignin

Reactivity of the aromatic rings in lignin in supercritical methanol at $270^{\circ} \mathrm{C}-27 \mathrm{MPa}$ has been reported in a previous paper ${ }^{15}$ by Tsujino et al. In this condition, 98\% of guaiacol (1), 99\% of veratrole (2), 91\% of 2,6-dimethoxyphenol (3) and 97\% of 1,2,3-trimethoxybenzene (4) were recovered after $10 \mathrm{~min}$ treatment. ${ }^{15}$ In addition, under the condition of $350^{\circ} \mathrm{C}-43 \mathrm{MPa}$, compounds (1), (2), (3) and (4) were found to be, respectively, recovered at 73, 81, 71 and 82\% in yields after 10min treatment. Although only small amounts of catechol and guaiacol were observed in the reaction mixtures of guaiacol (1) and veratrole (2), respectively, aromatic rings themselves are stable in supercritical methanol. Consequently, aromatic rings of softwood and hardwood lignins consisting, respectively, of guaiacyl type of nucleus and guaiacyl and syringyl types of nuclei can be stable under supercritical conditions of methanol.

Reactivity of condensed linkages

Reactivity of lignin was then investigated, focusing on the condensed linkages between phenylpropane $\left(\mathrm{C}_{6}-\mathrm{C}_{3}\right)$ units in lignin by using $5-5$ and $\beta-1$ types of dimeric lignin model compounds (5)-(7). Adler ${ }^{13}$ has reported as in Table 1 that 9.5-11 units of 5-5 structures exist in $100 \mathrm{C}_{6}-\mathrm{C}_{3}$ units in spruce lignin, but that this value is smaller to be 4.5 in birch lignin. For $\beta$ - 1 type structure, 7 units are reported for both spruce and birch lignins, and 15 for beech reported by Nimz. ${ }^{14}$ Therefore, these condensed structures are important linkages of lignin.

\section{5-5 type model compounds}

Figure 2 shows the HPLC chromatograms of the reaction mixtures obtained from phenolic and non-phenolic 5-5 type model compounds (5) and (6) as treated in supercritical 
methanol at $350^{\circ} \mathrm{C}-43 \mathrm{MPa}$. Reactivity of the biphenyl type model compounds in supercritical methanol at $270^{\circ} \mathrm{C}-27 \mathrm{MPa}$ has been already reported in the previous paper, ${ }^{15}$ in which compounds (5) and (6) were found to be recovered 78 and 91\%, respectively, after 10min treatment. ${ }^{15}$ Figure 2 shows the results at $350^{\circ} \mathrm{C}-43 \mathrm{MPa}$ that compounds (5) and (6) are recovered to be 71 and $88 \%$, respectively. Although unidentified compounds from these compounds are observed at the retention times of 32.3 and 29.6min, these are small in amounts so that biphenyl type model compounds are stable under the supercritical treatment of methanol. If 5-5 linkages of the biphenyl type model compounds are cleaved, 1-methyl-3-methoxyphenol and 1-methyl-3,4-dimethoxybenzene may be expected to be produced. However, these compounds were not the ones unidentified. In addition, GPC analysis indicated that monomeric compounds were not produced from compounds (5) and (6). Therefore, 5-5 linkages of phenolic and non-phenolic biphenyl type model compounds can hardly be cleaved in supercritical methanol.

\section{$\beta$-1 type model compound}

Figure 3 shows the HPLC chromatograms of the reaction mixtures obtained from non-phenolic $\beta$-1 type model compound (7) as treated in supercritical methanol at $270^{\circ} \mathrm{C}-27 \mathrm{MPa}$. As to $\beta-1$ model compound, it was found to be reactive in supercritical conditions. As reaction proceeded, the model compound (7) decreased and disappeared completely after 10 min treatment. The compounds (12) observed at 22.1 and $22.5 \mathrm{~min}$ in the retention time were identified to be erythro and threo isomers of $\alpha$-methyl ether of the compound (7) by comparison with the authentic samples. These compounds increased gradually at an early stage of the treatment and decreased after 5 min treatment. In turn, a peak which actually consists of two products observed at $29.2 \mathrm{~min}$ in the retention time was gradually increased. These newly formed products were identified to be cis and trans isomers of 
3,3',4,4'-tetramethoxystilbene (13) determined by ${ }^{1} \mathrm{H}-\mathrm{NMR}$ and GC-MS analysis. Finally, the compounds (7) and (12) disappeared completely and only the compound (13) was present with some other small peaks. This compound (13) was converted from non-phenolic $\beta-1$ model compound (7) by eliminating formaldehyde, and its $\beta$-1 linkage could not be cleaved.

Furthermore, cis and trans isomers of the compound (13) are stable in supercritical methanol. Maximal total yield of cis and trans isomers of the compounds (13) was found to be over $70 \mathrm{~mol} \%$ at both $270^{\circ} \mathrm{C}-27 \mathrm{MPa}$ and $350^{\circ} \mathrm{C}-43 \mathrm{MPa}$.

Finally, the proposed reaction pathway of non-phenolic $\beta-1$ model compound (7) is shown in Figure 4. Conversion of non-phenolic $\beta$-1 type model compound (7) into its $\alpha$-methyl ether is a dominant reaction path due to the acidic character of the supercritical methanol. ${ }^{16}$ Acid-labile hydroxyl groups such as $\alpha$-hydroxyl group in the compound (7) can be eliminated to form quinonemethide-type intermediate under such an acidic condition, which is easily converted into $\alpha$-methyl ether, and then further converted into tetramethoxystilbene (13), which is stable in supercritical methanol.

Based on these lines of evidence, the quinonemethide-type intermediate must be produced in majority without cleaving the sidechain of the phenylpropane unit. Thus, $\beta-1$ linkages in lignin must be very stable and do not contribute to the depolymerization of lignin during supercritical methanol treatment.

Reactivity of ether linkages

Reactivity of lignin was further investigated, focusing on the ether linkages of lignin. Ether linkages (non-condensed linkages), which are represented by $\beta-O-4$ model compounds (8) and (9) and $\alpha-O-4$ model compounds (10) and (11), are important linkages of lignin, especially in hardwood as shown in Table 1. 
$\beta$-O-4 type model compounds ${ }^{15}$

Reactivity of $\beta-O-4$ type model compounds in supercritical methanol at $270^{\circ} \mathrm{C}-27 \mathrm{MPa}$ has been reported in the previous paper. ${ }^{15}$ The $\beta-O-4$ model compounds were found to be very reactive in supercritical methanol, especially in phenolic form (8). The proposed reaction paths of phenolic and non-phenolic $\beta-O-4$ model compounds are shown in Figure 5 . As reaction proceeded, the model compound (8) decreased and disappeared completely after 20 min treatment at $270^{\circ} \mathrm{C}-27 \mathrm{MPa}$. Subsequently, guaiacol (1) and coniferyl alcohol (14) were produced. Although the amount of guaiacol increased and levelled-off after 3min treatment, coniferyl alcohol increased up to 10min treatment and then decreased somewhat by further treatment. In turn, coniferyl alcohol $\gamma$-methyl ether (15) was gradually produced. At 20min treatment, yields of guaiacol (1) and the sum of coniferyl alcohol (14) and its $\gamma$-methyl ether (15) were both $87 \%$. Thus, phenolic $\beta-O-4$ model compound (8) was first converted into guaiacol and coniferyl alcohol, and the latter product was further methylated at $\gamma$-position as shown in Figure 5. Conversion of coniferyl alcohol into its $\gamma$-methyl ether is considered to be due to the acidic character of the supercritical methanol as discussed in the methylation of non-phenolic $\beta$-1 model compound (7). These lines of evidence indicate that phenolic $\beta$-ether structure is easily cleaved to give coniferyl alcohol type of structure and that this structure is further methylated at $\gamma$-position.

On the other hand, non-phenolic $\beta-O-4$ type lignin model compound (9) decreased as the reaction time proceeded and disappeared completely after 5 min treatment. The initially produced product was found to be $\alpha$-methyl ether of the compound (9) by ${ }^{1} \mathrm{H}-\mathrm{NMR}$ analysis. Acid-labile $\alpha$-hydroxyl group is easily methylated via a quinonemethide intermediate as discussed in the methylation of compound (7). After supercritical methanol treatment of $\alpha$-methyl ether of the non-phenolic $\beta-O-4$ compound (16), cis and trans isomers of 
2-(2'-methoxyphenoxy)-1-(3',4'-dimethoxyphenyl) ethene (17) were appeared, and then cleaved off to produce guaiacol (1) after 3min treatment. Therefore, it can be supposed that guaiacol (1) was produced after a cleavage of $\beta$-ether of these vinyl ether compounds (17). The formation of guaiacol, which is evidence of $\beta$-ether cleavage, is little at the first stage of the reaction. However, at the later of the reaction over 10min, guaiacol (1) appears to be produced with a decrease in the amount of the vinyl ethers (17). Thus, non-phenolic $\beta-O-4$ model compound (9) must be converted into its $\alpha$-methyl ether (16), then into vinyl ethers (12), followed by the successive cleavage of $\beta$-ether linkage, as shown in Figure 5.

$\alpha-O-4$ type model compounds

The $\alpha-O-4$ model compounds were also found to be very reactive in supercritical methanol. Especially, phenolic $\alpha-O-4$ model compound (10) was remarkably reactive. Figure 6 shows the HPLC chromatograms of the reaction mixtures obtained from phenolic $\alpha-O-4$ type model compound (10) as treated in supercritical methanol at $270^{\circ} \mathrm{C}-27 \mathrm{MPa}$. The model compound (10) disappeared completely after 1 min treatment. The products observed in the retention times of 23.1min and 24.1min were identified to be guaiacol (1) and 2-methoxy-4-(methoxymethyl)-phenol (18), respectively, by comparison with the authentic samples. These compounds (1) and (18) were present stably in supercritical methanol even after $10 \mathrm{~min}$ treatment at $270^{\circ} \mathrm{C}-27 \mathrm{MPa}$. Furthermore, this reaction was occurred at lower temperatures. For example, even in methanol at $70^{\circ} \mathrm{C}$, the model compound (10) disappeared completely after 10 min treatment, and guaiacol (1) and 2-methoxy-4-(methoxymethyl)-phenol (18) were produced.

On the other hand, Figure 7 shows the HPLC chromatograms of non-phenolic $\alpha-O-4$ type model compound (11) as treated in supercritical methanol at $270^{\circ} \mathrm{C}-27 \mathrm{MPa}$. As reaction proceeded, the model compound (11) decreased, whereas guaiacol (1), compounds (19), (20) 
and (21) were produced. The compounds (19) and (20) were identified to be

1,2-dimethoxy-4-(methoxymethyl)-benzene and 3,4-dimethoxytoluene, respectively, by comparison with the authentic samples. The compounds (21) were also identified to be isomers of 1-guaiacyl-1-veratrylmethane by ${ }^{1} \mathrm{H}-\mathrm{NMR}$ analysis.

Consequently, it is indicated that both phenolic and non-phenolic $\alpha-O-4$ linkages in lignin can be cleaved in supercritical methanol. Finally, the reactions of phenolic and non-phenolic $\alpha-O-4$ model compounds take place as shown in the proposed reaction pathways in Figure 8. In case of phenolic model compound (10), it is converted rapidly into guaiacol (1) and quinonemethide-type intermediate by cleavage of $\alpha$-ether linkage, then 2-methoxy-4-(methoxymethyl)-phenol (18) being produced from the quinonemethide by methanolysis. These compounds (1) and (18) are stable in supercritical methanol. On the other hand, in case of non-phenolic model compound (11), it is converted into guaiacol (1) and quinonemethide-type intermediate, then the quinonemethide being converted into 1,2-dimethoxy-4-(methoxymethyl)-benzene (19) in a similar manner as above. Concomitantly, the diphenylmethane-type compounds (21) are produced by transformation of non-phenolic $\alpha$-O-4 model compound (11). The quinonemethide-type intermediate from non-phenolic compound (11) is supposed to be more reactive than that from phenolic compound (10), therefore, a part of the former intermediate is more likely to react with guaiacol to produce diphenylmethanes.

On the other hand, it was confirmed that 3,4-dimethoxytoluene (20) was produced from 1,2-dimethoxy-4-(methoxymethyl)-benzene (19) by the treatment of isolated compound (19) in supercritical methanol. Similarly, the compound (20) is expected to be directly produced from model compound (11) by cleavage of $\alpha$-ether linkage. However, it has not been clear yet. 


\section{Kinetics of cleavage in ether linkages of lignin}

Based on the results obtained above, $\beta-O-4$ and $\alpha-O-4$ linkages of lignin are concluded to be cleaved in supercritical methanol, whereas 5-5 and $\beta-1$ linkages to be stable. In addition, it was found that the cleavages of ether linkages of $\beta-O-4$ and $\alpha-O-4$ structures resulted in the formation of guaiacol. Therefore, the cleavage velocities of these ether linkages were evaluated, based on the amount of guaiacol produced by supercritical methanol treatment.

Assuming that the formation of guaiacol was the pseudo-first-order reaction, the rate constant $(\kappa)$ of cleavage was defined by the following equation:

$$
G=[1-\exp (-\kappa t)] \times 100(\mathrm{~mol} \%)
$$

where $G$ is the amount of guaiacol formed at an early stage of the reaction as a measure of the cleavage of the ether linkages, because guaiacol slightly decreased as the supercritical treatment proceeded.

Figure 9 shows the obtained Arrhenius plots for rate constants of cleavage in various ether linkages. The rate constants of phenolic and non-phenolic $\beta-O-4$ linkages were faster than that of non-phenolic $\alpha-O-4$ linkage and the rate constant of phenolic $\beta-O-4$ linkage was faster than that of non-phenolic $\beta-O-4$ linkage in every treatment temperature. Besides, the rate constant of any linkage continuously and linearly changed on the Arrhenius plot in a range between $180^{\circ} \mathrm{C}$ and $350^{\circ} \mathrm{C}$. Thus, any peculiar change in rate constant was not observed, even if the state of methanol changed to the supercritical state from the subcritical state. On the other hand, activation energies $\left(E_{\mathrm{a}}\right)$ for cleavages of phenolic $\beta-O-4$, non-phenolic $\beta-O-4$ and non-phenolic $\alpha-O-4$ linkages were 68.9, 85.2 and $113 \mathrm{~kJ} / \mathrm{mol}$, respectively. Therefore, the rate constants of non-phenolic $\beta-O-4$ and $\alpha-O-4$ linkages will be closer to that of phenolic $\beta-O-4$ 
linkage in highly elevated temperatures.

Reactivity of various linkages of lignin

Table 2 shows a summary of the lignin model compound study on the various linkages of lignin in supercritical methanol at $270^{\circ} \mathrm{C}-27 \mathrm{MPa}$. It is quite apparent that the condensed linkages of 5-5 and $\beta-1$ structures are stable in supercritical methanol, whereas the ether linkages of $\beta-O-4$ and $\alpha-O-4$ structures are readily cleaved. Therefore, the lignin in wood must be depolymerized in supercritical methanol mainly by cleaving the ether linkages of lignin.

Reactivity of lignin in wood

The kinetic study on the decomposition of lignin in wood has been also made in another work, ${ }^{6}$ to estimate the decomposition rate constant of lignin by assuming that the change of methanol-soluble portion follows pseudo-first-order kinetics. As a result, the decomposition rate constants of lignin in Japanese beech, buna (Fagus crenata) and Japanese cedar, sugi (Cryptomeria japonica) were reported to be $5.0 \times 10^{-3} \mathrm{sec}^{-1}$ and $0.31 \times 10^{-3} \mathrm{sec}^{-1}$, respectively, at $270^{\circ} \mathrm{C}-27 \mathrm{MPa}{ }^{6}$ Thus, the decomposition rate constant of lignin in beech was larger than that of cedar. It was further indicated that observed differences are mainly originated from intrinsic properties in lignin structure between softwood and hardwood as shown in Table 1; hardwood lignin which has more ether linkages is readily depolymerized and liquefied in supercritical methanol, compared with softwood lignin. On the other hand, activation energies for decomposition of lignin in beech and cedar woods were 88.4 and 62.4 $\mathrm{kJ} / \mathrm{mol}$, respectively, at relatively low temperatures $\left(180-250^{\circ} \mathrm{C}\right)$. These values are close to the 
rate constants of $\beta-O-4$ linkages shown in Table 2, for phenolic $68.9 \mathrm{~kJ} / \mathrm{mol}$ and non-phenolic $85.2 \mathrm{~kJ} / \mathrm{mol}$. It is, therefore, indicated that the $\beta-O-4$ linkages which are dominant in linkages of lignin mainly contribute to depolymerization of lignin in wood. This indication further suggests that the remaining lower molecular products of lignin are rich in the condensed linkages, as demonstrated by Minami and Saka ${ }^{6}$ with the alkaline nitrobenzene oxidation analysis.

\section{Conclusion}

The reactivity of lignin was investigated in this work focusing on the $5-5, \beta-1, \beta-O-4$ and $\alpha-O-4$ linkages of lignin by using some lignin model compounds. As a result, both $5-5$ and $\beta$-1 linkages were stable in supercritical methanol, whereas both $\beta-O-4$ and $\alpha-O-4$ linkages were cleaved rapidly. Therefore, it is suggested that the supercritical methanol treatment is effective to depolymerize lignin into the lower molecular products by cleaving the ether linkages of lignin. 


\section{Acknowledgments}

This research has been done under the research program for development of technologies for establishment of eco-system based on recycling in rural villages for the 21st century from the Ministry of Agriculture, Forestry and Fisheries, Japan, by a Grant-in-Aid for Scientific Research (B)(2) (No.12460144, 2001.4-2003.3) from the Ministry of Education, Culture, Sports, Science and Technology, Japan, and under the research program from Kansai Research Foundation for Technology Promotion, Japan, for which the authors thank in their financial supports. 


\section{References}

1. Ishikawa Y, Saka S (2001) Chemical conversion of cellulose as treated in supercritical methanol. Cellulose 8: 189-195

2. Saka S, Ueno T (1999) Chemical conversion of various celluloses to glucose and its derivatives in supercritical water. Cellulose 6: 177-191

3. Saka S, Konishi R (2001) Chemical conversion of biomass resources to useful chemicals and fuels by supercritical water treatment. In: Bridgwater AV (ed) Progress in Thermochemical Biomass Conversion. Blackwell Sci., Oxford, pp 1338-1348

4. Ehara K, Saka S, Kawamoto H (2002) Characterization of the lignin-derived products from wood as treated in supercritical water. J. Wood Sci. (in press)

5. Saka S, Kusdiana D (2001) Biodiesel fuel from rapeseed oil as prepared in supercritical methanol. Fuel 80: 225-231

6. Minami E, Saka S (2002) A comparative study of decomposition behaviors between hardwood and softwood in supercritical methanol. J. Wood Sci. (in press)

7. Yokoyama C, Nishi K, Nakajima A, Kiyono K (1998) Thermolysis of organosolv lignin in supercritical water and supercritical methanol. J. Japan Petroleum Inst. 41(4): 243-250

8. Yokoyama C, Nishi K, Otake K, Takahashi S (1994) Thermolysis of dibenzyl ether in supercritical methanol. J. Japan Petroleum Inst. 37(1): 34-44

9. Yokoyama C, Nishi K, Takahashi S (1997) Thermolysis of benzyl phenyl ether in subcritical and supercritical water, and supercritical methanol. J.Japan Petroleum Inst. 40(6): 465-473

10. Kratzl K, Vierhapper FW (1971) Synthese von C-kernmarkierten Vanillinen und Bikreosolen. Monatsh. Chem. 102: 425-430 
11. Kristersson P, Lundquist K (1980) A new synthetic route to lignin model compounds of the 1,2-Diaryl-1.3-propanediol type. Acta Chemica Scandinavica B 34: 213-234

12. Nakatsubo F, Sato K, Higuchi T (1975) Synthesis of guaiacylglycerol- $\beta$-guaiacyl ether. Holzforsch. B 29: 165-168

13. Adler E (1977) Lignin chemistry - Past, Present and Future. Wood Sci. Tech. 11(3): $169-218$

14. Nimz H (1974) Beech lignin - Proposal of a constitutional scheme. Angewandte Chemie 13: $313-321$

15. Tsujino J, Kawamoto H, Saka S (2002) Reactivity of lignin in supercritical methanol studied with some lignin model compounds. Wood Sci. Tech. (in press)

16. Wu BC, Klein MT, Sandler SI (1990) The benzylphenylether thermolysis mechanism: Insights from phase behavior. AIChE J 36 (8): 1129-1136 
Table 1. Number of different types of linkages upon 100 phenylpropane $\left(\mathrm{C}_{6}-\mathrm{C}_{3}\right)$ units involved in softwood and hardwood lignins. ${ }^{13,14}$

\begin{tabular}{|c|c|c|c|c|c|c|c|c|}
\hline & \multirow{3}{*}{ Species } & \multicolumn{7}{|c|}{ Number of linkages upon $100 \mathrm{C}_{6}-\mathrm{C}_{3}$ units } \\
\hline & & \multicolumn{4}{|c|}{ Condensed linkage } & \multicolumn{3}{|c|}{ Ether linkage } \\
\hline & & $5-5$ & $\beta-1$ & $\beta-\beta$ & $\beta-5$ & $\beta-O-4$ & $\alpha-O-4$ & $5-\mathrm{O}-4$ \\
\hline Softwood & Spruce (Picea abies) ${ }^{13}$ & $9.5-11$ & 7 & 2 & $9-12$ & 50 & $6-8$ & $3.5-4$ \\
\hline \multirow[t]{2}{*}{ Hardwood } & Birch (Betula verrucosa) ${ }^{13}$ & 4.5 & 7 & 3 & 6 & 62 & $6-8$ & 6.5 \\
\hline & Beech (Fagus crenata) $)^{14}$ & 2.3 & 15 & 7.5 & 6 & \multicolumn{2}{|c|}{65} & 1.5 \\
\hline
\end{tabular}


Table 2. Cleavage rate, rate constant $(\kappa)$ of cleavage and activation energy $\left(E_{\mathrm{a}}\right)$ in the various linkages of the lignin model compounds in supercritical methanol at $270^{\circ} \mathrm{C}-27 \mathrm{MPa}$.

\begin{tabular}{|c|c|c|c|c|c|c|c|}
\hline \multirow{3}{*}{ Item } & \multicolumn{3}{|c|}{ Condensed linkage } & \multicolumn{4}{|c|}{ Ether linkage } \\
\hline & \multicolumn{2}{|c|}{$5-5$} & \multirow{2}{*}{$\begin{array}{c}\beta-1 \\
\text { Non-ph }\end{array}$} & \multicolumn{2}{|c|}{$\beta-O-4$} & \multicolumn{2}{|c|}{$\alpha-O-4$} \\
\hline & $\mathrm{Ph}$ & Non-ph & & $\mathrm{Ph}$ & Non-ph & $\mathrm{Ph}$ & Non-ph \\
\hline Cleavage rate* & $x$ & $\times$ & $x$ & O & 0 & (0) & $\bigcirc$ \\
\hline$\kappa\left(10^{-3} \mathrm{sec}^{-1}\right)$ & - & - & - & 2.8 & 0.34 & $* *$ & 0.17 \\
\hline$E_{\mathrm{a}}(\mathrm{kJ} / \mathrm{mol})$ & - & - & - & 68.9 & 85.2 & $* *$ & 113 \\
\hline
\end{tabular}

* (); Extremely high, $\bigcirc$; High, $\times$; Low. ${ }^{* *}$ Not measurable because of the high reactivity 


\section{List of figures}

Fig .1 Lignin model compounds used in this study.

Fig. 2 HPLC chromatograms of phenolic biphenyl (5) and non-phenolic biphenyl type lignin model compounds as treated in supercritical methanol at $350^{\circ} \mathrm{C}-43 \mathrm{MPa}$. (Column: STR ODS-II, Detector: $\mathrm{UV}_{280 \mathrm{~nm}}$, Eluent: $\mathrm{MeOH} / \mathrm{H}_{2} \mathrm{O}=20 / 80 \rightarrow 100 / 0(0 \rightarrow 30 \mathrm{~min})$, Flow rate: $\left.0.8 \mathrm{ml} / \mathrm{min}\right)$

Fig. 3 HPLC chromatograms of non-phenolic $\beta$-1 (7) lignin model compound as treated in supercritical methanol at $270^{\circ} \mathrm{C}-27 \mathrm{MPa}$. (Column: STR ODS-II, Detector: UV280 $\mathrm{nm}$, Eluent: $\mathrm{MeOH} / \mathrm{H}_{2} \mathrm{O}=20 / 80 \rightarrow 100 / 0(0 \rightarrow 30 \mathrm{~min})$, flow rate: $\left.0.8 \mathrm{ml} / \mathrm{min}\right)$

Fig. 4 Major degradation pathway of non-phenolic $\beta$-1 lignin model compound (7) as treated in supercritical methanol.

Fig. 5 Degradation pathways of phenolic and non-phenolic $\beta-O-4$ model compounds, (8) and (9), as treated in supercritical methanol. ${ }^{15}$

Fig. 6 HPLC chromatograms of phenolic $\alpha-O-4$ (10) lignin model compound as treated in supercritical methanol at $270^{\circ} \mathrm{C}-27 \mathrm{MPa}$. (Column: STR ODS-II, Detector : $\mathrm{UV}_{280 \mathrm{~nm}}$, Eluent: $\mathrm{MeOH} / \mathrm{H}_{2} \mathrm{O}=20 / 80 \rightarrow 60 / 40 \rightarrow 100 / 0(0 \rightarrow 40 \rightarrow 50 \mathrm{~min})$, flow rate $\left.: 0.8 \mathrm{ml} / \mathrm{min}\right)$

Fig. 7 HPLC chromatograms of non-phenolic $\alpha-O-4$ (11) lignin model compound as treated in supercritical methanol at $270^{\circ} \mathrm{C}-27 \mathrm{MPa}$. (Column: STR ODS-II, Detector : $\mathrm{UV}_{280 \mathrm{~nm}}$, Eluent: $\mathrm{MeOH} / \mathrm{H}_{2} \mathrm{O}=20 / 80 \rightarrow 100 / 0(0 \rightarrow 30 \mathrm{~min})$, flow rate $\left.: 0.8 \mathrm{ml} / \mathrm{min}\right)$ 
Fig. 8 Degradation pathways of phenolic and non-phenolic $\alpha-O-4$ model compounds, (10) and (11), as treated in supercritical methanol.

Fig. 9 Arrhenius plots for rate constants of cleavage in $\beta$-ether and $\alpha$-ether linkages. Filled squares, phenolic $\beta$-O-4 (8); Open squares, non-phenolic $\beta-O-4$ (9); Open triangles, non-phenolic $\alpha-O-4$ (11). 
<smiles>[R]Oc1ccccc1OC</smiles>

(1) : $\mathrm{R}=\mathrm{H}$

(2) : $\mathbf{R}=\mathrm{CH}_{3}$<smiles>COc1ccc(C(O)C(CO)c2ccc(OC)c(OC)c2)cc1OC</smiles>

(7)<smiles>[R2]c1c(OC)cccc1OC</smiles>

(3) : R=H

(4) : $\mathrm{R}=\mathrm{CH}_{3}$

(5) : R=H

(6) : $\mathrm{R}=\mathrm{CH}_{3}$<smiles>[R20]c1ccc(C(O)C(CO)Oc2ccccc2OC)cc1OC</smiles>

(8) : R=H

(9) : $\mathrm{R}=\mathrm{CH}_{3}$<smiles>[R]Oc1ccc(COc2ccccc2OC)cc1OC</smiles>

(10) : $\mathrm{R}=\mathrm{H}$ (11) : $\mathrm{R}=\mathrm{CH}_{3}$ 


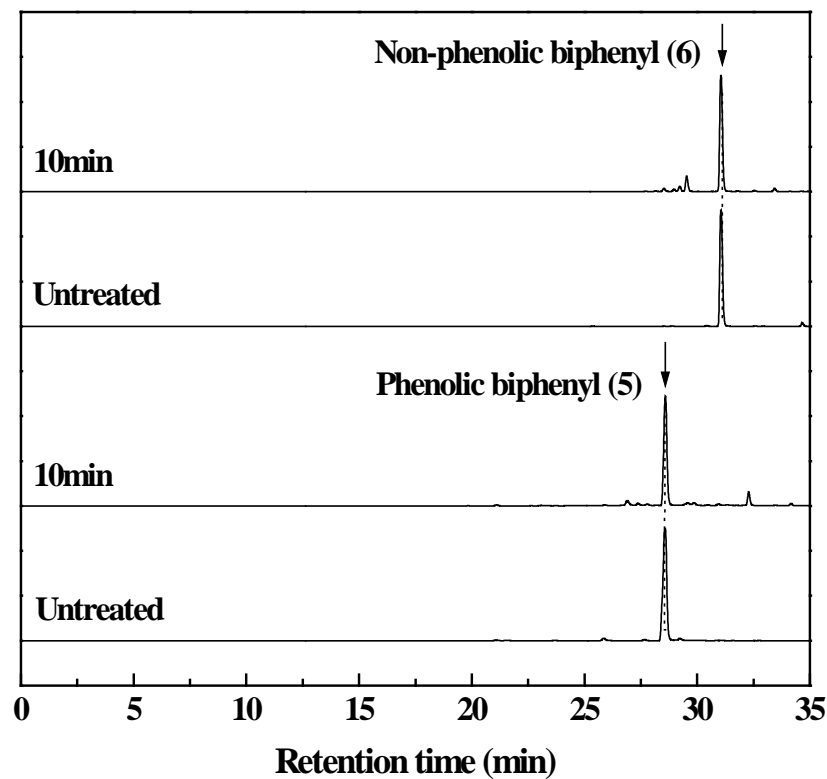




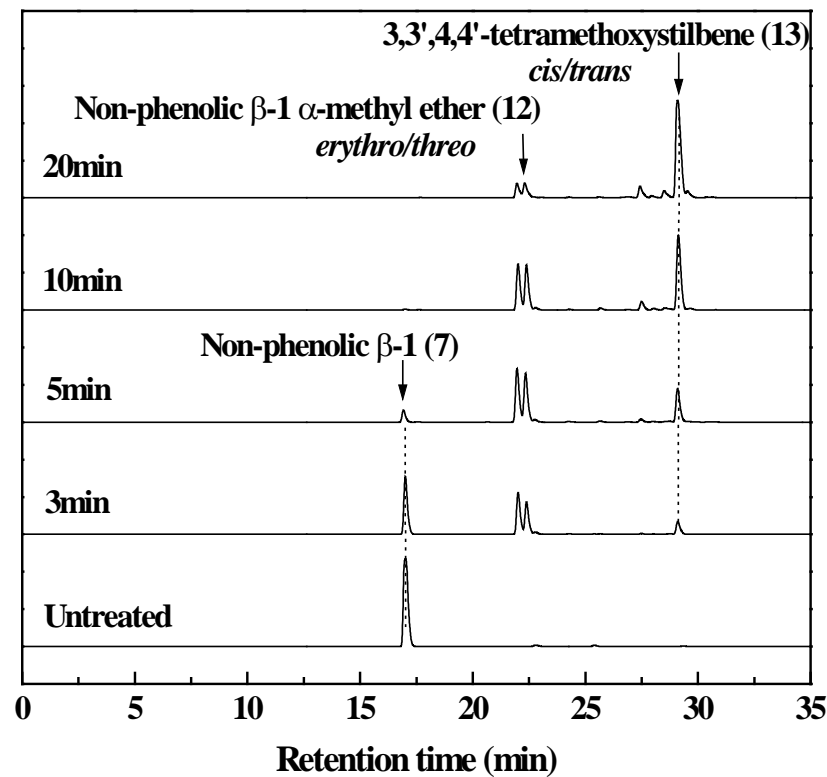




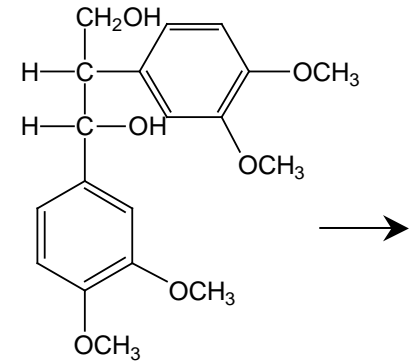

(7)

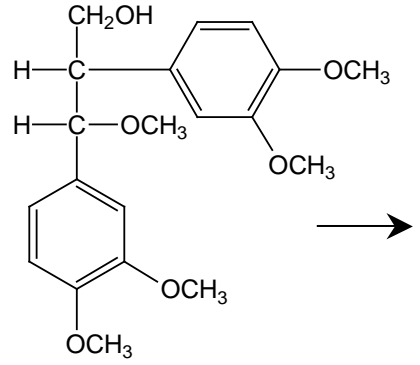

(12) (erythro/threo)<smiles>COc1ccc(/C=C/c2ccc(OC)c(OC)c2)cc1OC</smiles>

(13) 
<smiles>COc1cc(C(O)C(CO)Oc2ccccc2OC)ccc1O</smiles>

(8)

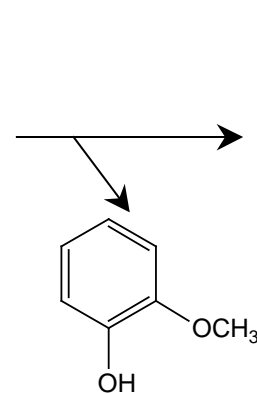

(1)

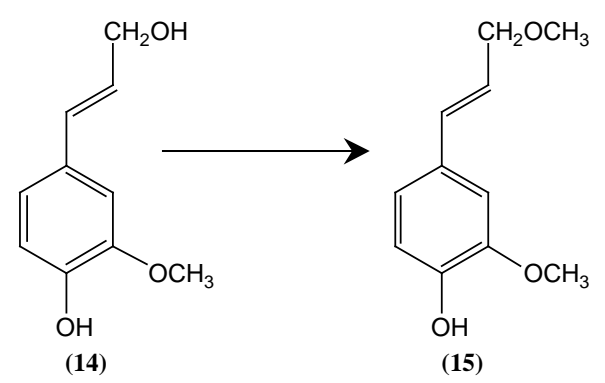

(15)<smiles>COc1ccc(C(O)C(CO)Oc2ccccc2OC)cc1OC</smiles>

(9)

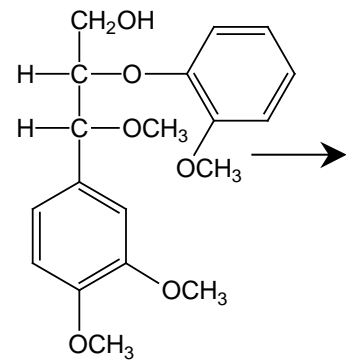

(16)

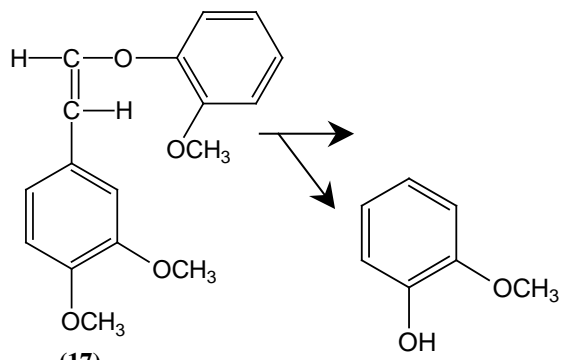

(1) 


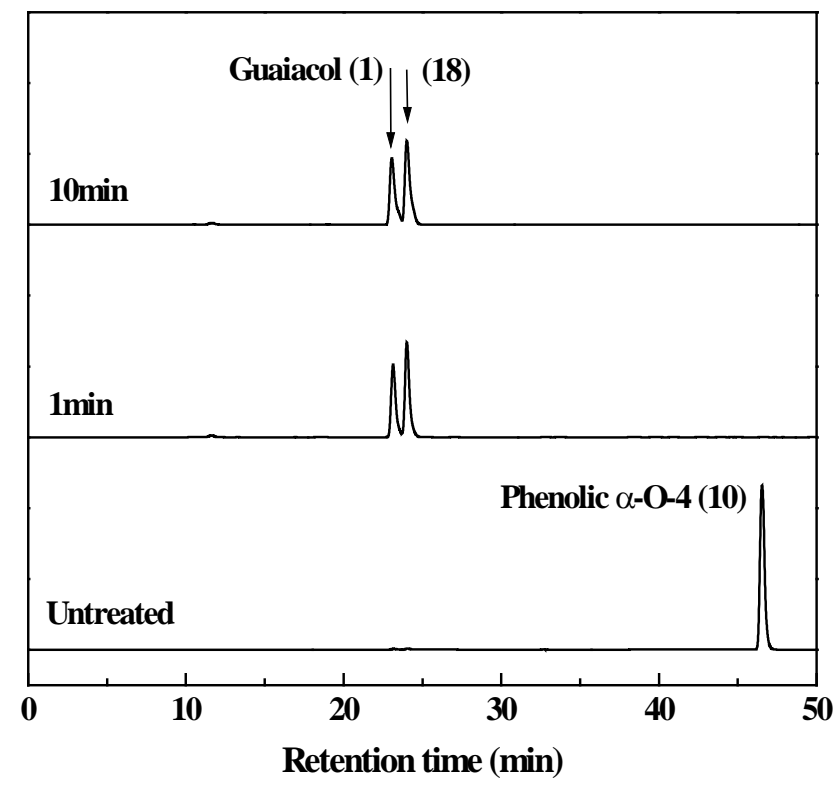




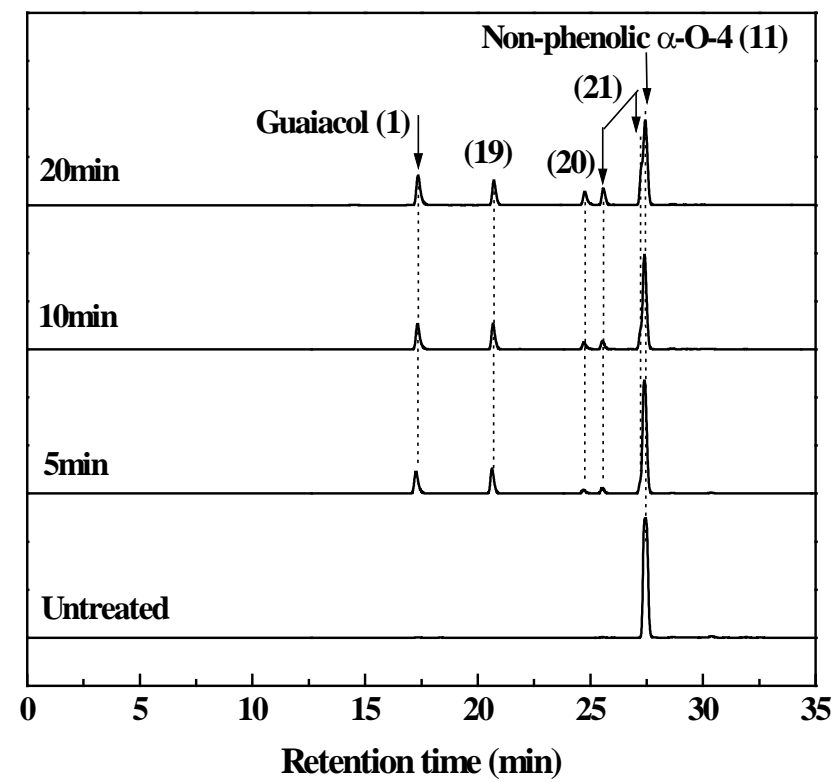


<smiles>COc1cc(COc2ccccc2OC)ccc1O</smiles>

(10)

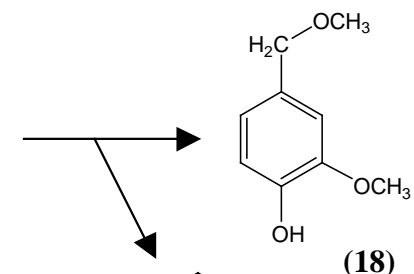<smiles>COc1ccccc1O</smiles>

(1)

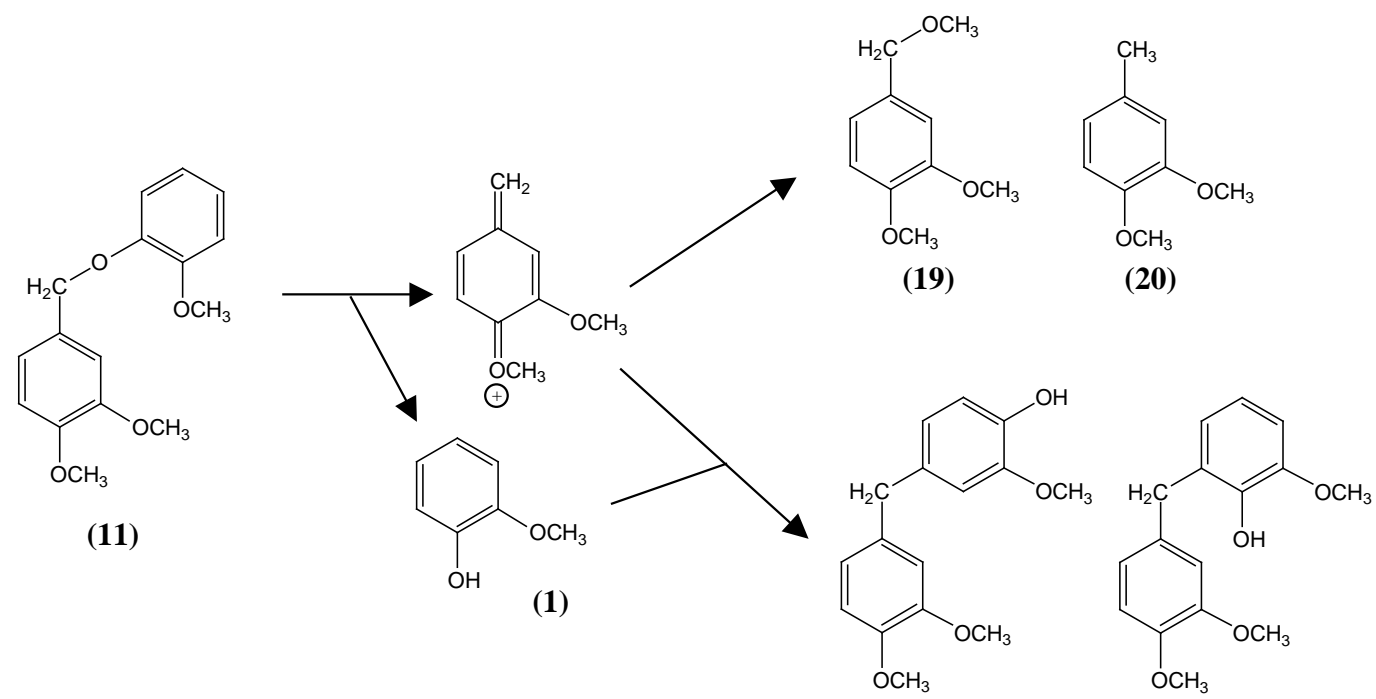

(21) 


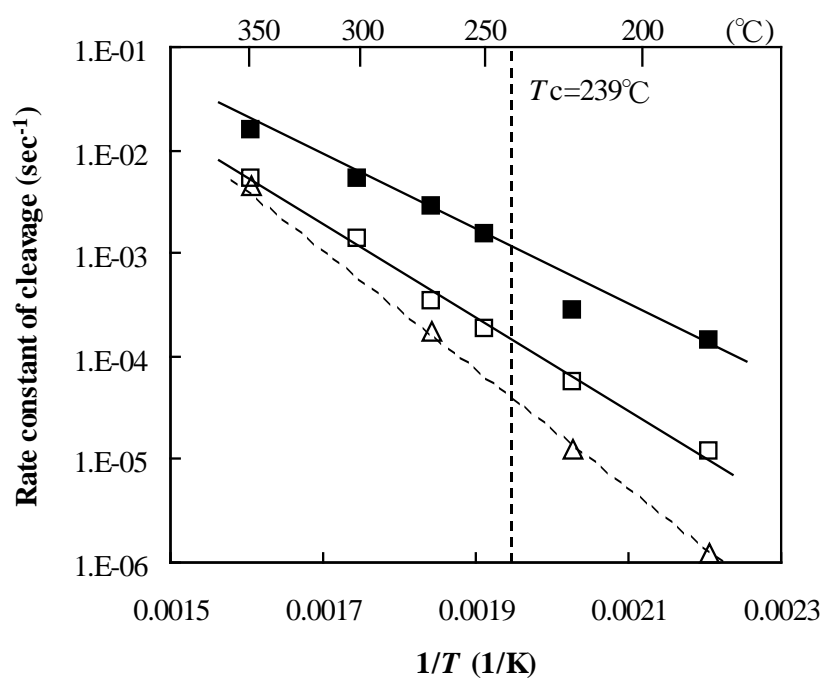

